\title{
Dormancy Breaking in Senna Pendula (Willd.) H. S. Irwin \& Barneby
}

\author{
Josinei Rodrigues Filho' (D), Viviana Borges Corte $^{2}$ (D), \\ Idalina Tereza de Almeida Leite Perin ${ }^{2}$
}

${ }^{1}$ Programa de Pós-graduação em Biologia Vegetal, Universidade Federal do Espirito Santo - UFES, Vitória/ES, Brasil ${ }^{2}$ Departamento de Ciências Biológicas, Universidade Federal do Espirito Santo - UFES, Vitória/ES, Brasil

\begin{abstract}
Senna pendula seeds dormancy is caused by impermeability of the seed coat to water. In order to determine the best methodology to overcome dormancy and to perform a morphological characterization, two batches of seeds were submitted to the following treatments: a) mechanical scarification of the seed coat; b) immersion in hot water at $70{ }^{\circ} \mathrm{C}$ for $5,10,15$ and 20 minutes; c) immersion in hot water at $90^{\circ} \mathrm{C}$ for $5,10,15$ and 20 minutes; d) sulfuric acid concentrate for 5, 10, 15 and 20 minutes; e) no treatment. The experiment was conducted in laboratory using a completely randomized design, with four replications of 25 seeds each, with daily verification for 7 days. The results showed that the use of water does not overcome the dormancy, however mechanical and chemical scarifications were the most effective treatments, with germination percentage of up to $94 \%$.
\end{abstract}

Keywords: germination, tegument, vigor. 


\section{INTRODUCTION}

Seeds originated by the sexual reproduction of plants promote genetic variability of the population, and their dispersion provides the conquest of new environments, to the extent of the success of germination. The blocking of the germination process of intact and viable seeds, even in satisfying favorable environmental conditions, is called dormancy (Goudel et al., 2013). This is evolutionarily acquired mechanism is a promising adaptation for survival of the species to harsh environments and in long term (Hilhorst, 2007). The germination impediment is very common in the botanical family Fabaceae and in species of the pioneers' ecological group (Bewley \& Black, 1994). Physical dormancy is the most common in this species (Perez, 2004; Pereira \& Jacobi, 2014).

Many species of the Fabaceae family present dormancy because of the hardness of the integument, and thus are waterproof. In the genus Senna Mill., composed of 260 species (Rodrigues et al., 2005), many species have dormant seeds, as Senna occidentalis (L.) Linck. Handb.), Senna siamea (Lam.) H. S. Irwin and Barneby and Senna spectabilis (DC.) Irwin and Barneby (Floriano, 2004; Topanotti et al., 2014).

Dormancy, although important in ecological terms, is one of the great difficulties in the sexual propagation process, because it hinders the uniform production of seedlings (Dutra et al., 2015). Therefore, several studies have been developed aiming to improve techniques for overcoming seed dormancy in this family (Alves et al., 2004; Lopes et al., 2012; Pereira et al., 2014).

Physical dormancy is established when the seed coat, impermeable to water and gases, is the main modulator in the interaction between the internal tissues of the seed and the environment (Hilhorst, 2007). In some species, on the ripening stage, the seeds can be coated with suberin and/or lipids, making them waterproof. The impermeability is normally associated with the presence of one or more layers of palisade cells with lignified thick wall, mucilage in the testa and serous cuticle (Baskin \& Baskin, 2004; Perez, 2004). This barrier formed by the palisade cells in the seeds of Fabaceae is a hereditary feature and causes a physical blocking, preventing both imbibition as the oxygenation of the embryo. In this sense, there are many methods to overcome dormancy in species of this family, among which mechanical scarification, chemical and immersion in hot water stand out, all of them aiming to overcome the integument impermeability (Agra et al., 2015).

The demand for studies of morphophysiological characteristics of native forest species is growing because of their economic and environmental potential use. Among the species of native Fabaceae is Senna pendula (Willd.) HS Irwin \& Barneby, a pioneer species, found mainly in the Atlantic Forest (Souza \& Bortoluzzi, 2016), widely used in reforestation and landscaping due to its yellow and showy flowers (Alves \& Sartori, 2009).

In one of the few studies on the species, Alzugaray et al. (2007) recommends chemical treatment with sulfuric acid for 10 minutes to overcome dormancy. However, there is still little information on dormancy breaking, germination and storage processes that can enable production of more efficient and uniform seedlings.

Because of their environmental and landscaping potential and therefore, great interest in the nursery production of viable seedlings, it is important to better standardize their germination process. From this observation, this study aimed to morphologically characterize the $S$. pendula seeds, and evaluate the effectiveness of various treatments to overcome dormancy in two batches of seeds of different ages.

\section{MATERIAL AND METHODS}

The work was carried out at the Seed Laboratory and Forest Ecophysiology of the Federal University of Espirito Santo (UFES) in Vitoria - ES.

Two batches of Senna pendula seeds were collected in 2011 and 2014 from five trees located in natural areas of the city of Piracicaba -SP. After collection, the seeds were taken to the Institute of Forestry Research and Studies (IPEF) also in Piracicaba (SP) and stored in a cold chamber at $10{ }^{\circ} \mathrm{C}$ and $50 \%$ humidity.

\subsection{Morphological characterization}

For the morphological analysis, the length and width of seeds were obtained with the aid of a digital caliper rule using four replications of 25 seeds each, and the results were expressed in $\mathrm{mm}$.

To determine the weight of a thousand seeds, eight replications of 100 seeds each were used, following the established by Brasil (2009). 


\subsection{Seed moisture content}

The moisture content of the seeds for the physical evaluation was determined. For this determination, we used three replications of 5 grams of seeds, which were weighed and submitted to an oven at $105^{\circ} \mathrm{C} \pm 3{ }^{\circ} \mathrm{C}$ for 24 hours (Brasil, 2009).

\subsection{Imbibition curve}

For the study of imbibition, we used 3 sub-samples of 10 intact and 10 mechanically scarified seeds for 30 seconds in the opposite side of the embryo. They were placed in Petri dishes with two sheets of filter paper moistened with distilled water in the proportion of three times its dry weight. Each subsample was weighed each hour for 10 hours in a scale with accuracy of $0.001 \mathrm{~g}$ (Kern, KB 360-3N).

\subsection{Dormancy breaking}

Four replications of 25 seeds were submitted to the following treatments to overcome dormancy: a) mechanical scarification of the seed coat in the opposite part of the embryo, with sandpaper No. 40 for 30 seconds; b) immersion in hot water at $70{ }^{\circ} \mathrm{C}$ for $5,10,15$ and 20 minutes; c) soaking in hot water at $90{ }^{\circ} \mathrm{C}$ for $5,10,15$ and 20 minutes; d) immersion in concentrate sulfuric acid $\left(\mathrm{H}_{2} \mathrm{SO}_{4}\right)$ for 5, 10, 15 and 20 minutes, followed by washing with running water; and e) seeds without treatment (control).

The seeds were then disinfected with sodium hypochlorite $2 \%$ for 2 minutes and placed in Petri dishes with two sheets of filter paper moistened with distilled water in the proportion of three times its dry weight and placed in BOD germination chamber, at constant temperature of $23^{\circ} \mathrm{C}$ and constant light for a seven days period (Ferreira \& Borghetti, 2004). The parameters analyzed were the germination percentage $(G)$, relative frequency $(R F)$ and the germination speed index (GSI).

The germination percentage ( $\% \mathrm{G})$ was calculated according to the number of normal seedlings, following the established by Brasil (2009).

The relative frequency was calculated using the daily germination count as Labouriau \& Valadares (1976) (Equation 1),
$\mathrm{Fr}=\mathrm{ni} / \sum \mathrm{ni}$

where $\mathrm{Fr}=$ relative frequency; $\mathrm{ni}=$ number of germinated seeds per day; and $\Sigma \mathrm{ni}=$ number of germinated seeds

The GSI was determined according to the methodology of Maguire (1962) (Equation 2),

$\mathrm{GSI}=\frac{\mathrm{G} 1}{\mathrm{~T} 1}+\frac{\mathrm{G} 2}{\mathrm{~T} 2}+\ldots+\frac{\mathrm{Gi}}{\mathrm{Ti}}$

wherein $\mathrm{GRI}=$ germination rate index; $\mathrm{G} 1$ to $\mathrm{Gi}=$ number of germinated seeds occurred every day; and $\mathrm{T} 1$ to $\mathrm{Ti}=$ time of evaluation days.

\subsection{Anatomical test}

The seeds were fixed in acetic alcohol Formalin-acid (FAA) $70 \%$ and then stored in 70\% alcohol. Later they were dehydrated using increasing alcoholic series, embedded in historesin (Leicester, Germany) and sectioned (10-12 $\mu \mathrm{m}$ thick) using rotary microtome (Jung AG Heidelberg) (Johansen, 1940).

The statistical design was completely randomized with four replications of 25 seeds each. When necessary data were expressed in percentage were transformed into " $\operatorname{arc} \sin (\sqrt{\mathrm{x}} / 100)$ ", to meet the normality according Lilliefors and homogeneity of variances by Cochran (Banzatto \& Kronka, 2006; Ribeiro, 2012); however, only the original data are shown. Data were submitted to analysis of variance (ANOVA), and the averages compared by Tukey test at $5 \%(\mathrm{p}<0.05)$ probability using the Assistat 7.7 software.

\section{RESULTS AND DISCUSSION}

Mature seeds of Senna pendula have flat and smooth shape and bright brown color. The morphometric analysis of seeds is found in Table 1.

The cross-section reveals a thick seed cutaneous layer separating the embryo from the external environment. It can be noted a double epidermal layer with the presence of macrosclereids in the underlying band, in contact with the mesophyll (Figure 1).

We observed, by seeds imbibition curves of both batches of $S$. pendula, a rapid imbibition and consequent increase in weight throughout the experiment (Figure 2). The same was not observed in intact seeds, which confirms the existence of a physical dormancy, thus preventing the absorption of water. 
Table 1. Physical characteristics of S. pendula seeds.

\begin{tabular}{ccc}
\hline Parameters & Batch $\mathbf{2 0 1 4}$ & Batch $\mathbf{2 0 1 1}$ \\
\hline Weight of 1000 seeds $(\mathrm{g})$ & 27.7 & 25.6 \\
Length $(\mathrm{mm})$ & 5.5 & 5.3 \\
Width $(\mathrm{mm})$ & 3.2 & 3.3 \\
Moisture Percentage & $13.8 \%$ & $10.1 \%$ \\
\hline
\end{tabular}
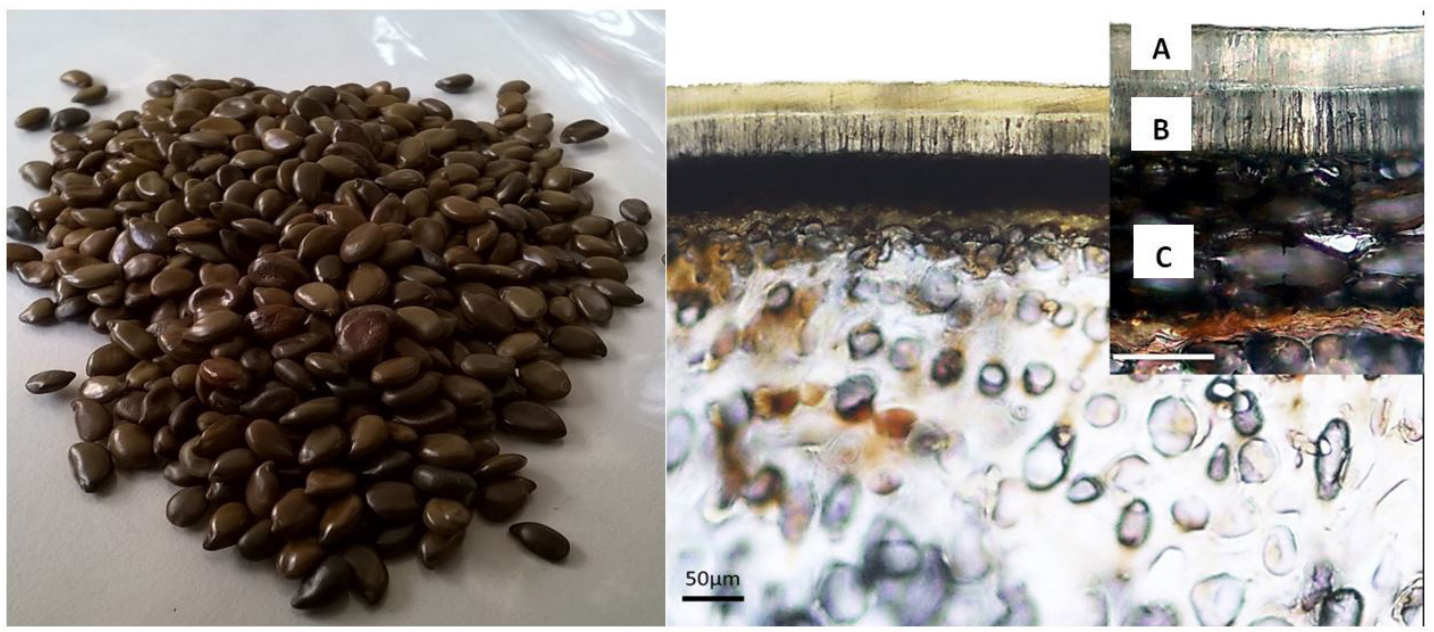

Figure 1. Characterization of Senna pendula seed: Seed overview and Histological cross section. (A) Epidermis; (B) Epidermis with the presence of macrosclereids; (C) Mesophyll.

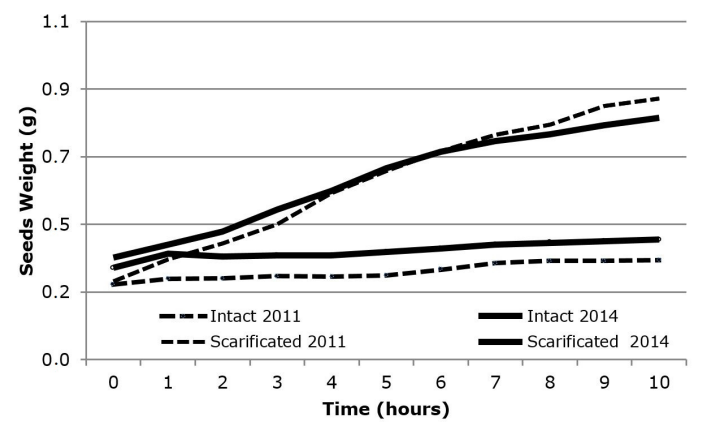

Figure 2. S. pendula seed imbibition curve intact and mechanically scarified with sandpaper.

In general, the untreated seeds, used as a control, did not show satisfactory germination percentage (Table 2), with maximum values of 10 and $12 \%$, for batches 2011 and 2014, respectively.

Dormancy established in the seed tends to be attenuated with time, either in the environment or storage (Fowler \& Bianchetti, 2000). Studies with sunflower show dormancy weakening with $80 \%$ germination percentage after 2 years of storage (Maeda et al., 1987).
The same was observed with seeds of Ilex paraguariensis (Yerba mate) and the genus Magnolia (Floriano, 2004).

Storage may have been responsible for a decline in the viability of the $S$. pendula seeds, as observed in Table 2. Even with the best treatments for breaking dormancy, in which the germination rates were above $80 \%$ in batch 2014 , the germination rate remained below $50 \%$ in the 2011 batch. The storage conditions can accelerate the deterioration processes in seeds (Marcos, 2005; Silva et al., 2010) and this may have been one of the factors for the decrease in the viability of seeds of 2011 batch. The deterioration is evidenced by genetic damage, loss of integrity of cell membranes, changes in respiratory activity and enzyme activity of seeds, which may cause delay in germination, uneven emergence and finally death of seeds (Santos et al., 2004).

Garcia (2013) worked with two batches of Senna rugosa, one new and other artificially aged, and also observed a decrease in the percentage of germination, with a significant difference between samples. In another study analyzing the deterioration suffered by the seeds over time, Ferreira et al. (2004) observed sharp decline of viability in $S$. macranthera seeds. 
Table 2. Germination percentage of different batches of S. pendula seeds under different dormancy breaking treatments.

\begin{tabular}{|c|c|c|}
\hline Treatments & Batch 2011 & Batch 2014 \\
\hline Control & $10 \mathrm{~A} \mathrm{e}$ & $12 \mathrm{Ag}$ \\
\hline Sandpaper n. 40 30" & $49 \mathrm{~A} \mathrm{a}$ & $94 \mathrm{Ba}$ \\
\hline Water $70^{\circ} \mathrm{C} 5^{\prime}$ & $17 \mathrm{~A} \mathrm{~d}$ & $22 \mathrm{Af}$ \\
\hline Water $70^{\circ} \mathrm{C} 10^{\prime}$ & $20 \mathrm{Ad}$ & $49 \mathrm{~B} \mathrm{e}$ \\
\hline Water $70^{\circ} \mathrm{C} 15^{\prime}$ & $19 \mathrm{~A} \mathrm{~d}$ & $52 \mathrm{~B} \mathrm{e}$ \\
\hline Water $70^{\circ} \mathrm{C} 20^{\prime}$ & $20 \mathrm{Ad}$ & $52 \mathrm{~B} \mathrm{e}$ \\
\hline Water $90^{\circ} \mathrm{C} 5^{\prime}$ & $11 \mathrm{~A} \mathrm{e}$ & $49 \mathrm{~B} \mathrm{e}$ \\
\hline Water $90^{\circ} \mathrm{C} 10^{\prime}$ & $0.0 \mathrm{Af}$ & $19 \mathrm{~B} \mathrm{f}$ \\
\hline Water $90^{\circ} \mathrm{C} 15^{\prime}$ & $0.0 \mathrm{Af}$ & $3 \mathrm{Ah}$ \\
\hline Water $90^{\circ} \mathrm{C} 20^{\prime}$ & $0.0 \mathrm{Af}$ & $4 \mathrm{~A} \mathrm{~h}$ \\
\hline $\mathrm{H}_{2} \mathrm{SO}_{4} 5^{\prime}$ & $44 \mathrm{~A} \mathrm{ab}$ & $80 \mathrm{Bd}$ \\
\hline $\mathrm{H}_{2} \mathrm{SO}_{4} 10^{\prime}$ & $39 \mathrm{Abc}$ & $91 \mathrm{Bab}$ \\
\hline $\mathrm{H}_{2} \mathrm{SO}_{4} 15^{\prime}$ & $37 \mathrm{Ac}$ & $88 \mathrm{~B} \mathrm{bc}$ \\
\hline $\mathrm{H}_{2} \mathrm{SO}_{4} 20^{\prime}$ & $39 \mathrm{~A} \mathrm{bc}$ & $85 \mathrm{Bcd}$ \\
\hline
\end{tabular}

Means followed by the same capital letter in line and lowercase letters in the column do not differ (5\% Tukey test). " = Seconds; ' $=$ Minutes.

For S. pendula seeds, the treatment with most promising result was scarification using sandpaper \# 40 for $0.5 \mathrm{~min}$, at which it was obtained $94 \%$ germination (seed batch of 2014), followed by immersion in sulfuric acid for 10 minutes, at which $91 \%$ of germinated seeds was obtained in the 2014 batch (Table 2). Treatment of scarification with sandpaper for 0.5 minute was the most promising for both 2011 and 2014 batches. The second best batchesresult for both batches was chemical scarification with sulfuric acid. However, the seeds of 2011 batch did not support as well the 10 minutes of exposure as the 2014 batch and the best results for the older batch occurred when subjected to acid for 5 minutes.

Santarém \& Aquila (1995) and Lopes et al. (2012) obtained similar results with Senna macranthera seeds, scarificated in the opposite area of the embryonic axis, resulting in the highest percentage of germination in relation to other treatments to overcome dormancy. However, Lopes et al. (2012) recommends the use of № 100 sandpaper, but without establishing for how long.

Despite the good results obtained to overcome seed dormancy of $S$. pendula with treatments by mechanical scarification with sandpaper and chemical with acid, the impact of the seed loss of viability due to deterioration over time is outstanding. This fact is evidenced when comparing the percentage of seed germination between the two batches studied (stored for 1 year and 4 years), subjected to the same treatments to overcome dormancy. The results obtained with chemical and mechanical scarification demonstrate the success of these methods in seeds with physical dormancy (integument). However, when subjected to hot water, we observed that the increase in temperature to $90^{\circ} \mathrm{C}$ caused severe damage to the embryo, resulting in the death of seeds from 10 minutes exposure to 2011 batch and 15 minutes to the 2014 batch. Bowdichia virgilioides seeds also showed impaired germination when subjected to hot water at $80^{\circ} \mathrm{C}$ (Albuquerque et al., 2007). These results show that, although the boiling water softens the outside of the seed and increase fluid absorption capacity, it can also denature both tegument as embryo proteins, affecting the viability and integrity of this proteins of seed tissues (Guedes et al., 2013).

The exposition to water $70^{\circ} \mathrm{C}$ did not cause damage to $S$. pendula seeds, but there was no significant increase in germination (Table 2). Although soaking in hot water is considered a practical method to overcome dormancy (Santarém \& Aquila, 1995), including seeds of Senna obtusifolia (Topanotti et al., 2014), its effectiveness could not be confirmed for Senna pendula.

The results observed for the two batches showed the decrease in the germination percentage and seed vigor from the 2011 batch (four years in cold chamber). Although the vigor is determined primarily by genetic component, thus species-specific, post-harvest handling and environmental conditions are relevant (Flávio, 2014). For the species Calliandra foliolosa Benth., another 
Fabaceae, stored in cold chamber, at $5^{\circ} \mathrm{C}$, the germination percentage was maintained, as well as the vigor, even after 4 years of storage (Calil et al., 2008). For Senna seeds, stored in the same temperature conditions in cold chamber, we observed that in only 240 days there was loss in the vigor and the GSI values were reduced (Rodrigues, 2013). However, in S. macranthera seeds also kept at $5^{\circ} \mathrm{C}$, but coated with polymeric blanket, it was not observed a sharp decrease in germination rate and viability after 380 days (Pozitano, 2011).

The conditions and the storage period influenced the seed vigor of $S$. pendula, despite being considered an orthodox species. This can also be seen in the treatment with hot water at $90{ }^{\circ} \mathrm{C}$ for both batches, which, with vigor decrease, did not support the thermal stress, not reaching satisfactory germination percentages $(<50 \%)$.

The temperature and relative humidity have major role to ensure the longevity and viability of seeds during storage (Pinho et al., 2009), and a rise in the values of these two factors may increase the seeds deterioration (Garcia et al., 2014).

Thus, it is estimated that, even being a pioneer species with physical dormancy, which would ensure a long period of longevity (Carvalho et al., 2006), the $S$. pendula seeds have demonstrated its viability affected over four years of storage, under the conditions in which they were stored $\left(10^{\circ} \mathrm{C} / 50 \% \mathrm{RH}\right)$. It is suggested, for this species, storage at a lower humidity and temperatures around $5{ }^{\circ} \mathrm{C}$, as established by several authors, including Fabaceae species (Borges et al., 2009; Aguiar et al., 2010).

The treatments with higher germination percentage (mechanical scarification with sandpaper and $\mathrm{H}_{2} \mathrm{SO}_{4}$ for 10 minutes) (Table 2) showed GSI equal to 24.85 and 28.15 respectively for the 2014 batch (Table 3 ), demonstrating that these methods, by causing the weakening of the seed coat, enable immersion and subsequent germination. These values show a significant difference when compared with the Batch of 2011. This decrease in GSI supports the Smaniotto et al. (2014) who reported decrease in the viability and GSI of soybeans after 6 months of storage, as a result of natural deterioration process of seeds.

Souza et al. (2005), in their work with seed Tabebuia serratifolia also observed along the storage for six months the loss of force and decrease of the GSI. The same could be observed in Dalbergia nigra seeds stored for 2 years in cold chamber (Aguiar et al., 2010).

The seeds show a growing trend of GSI when subjected to hot water $\left(70{ }^{\circ} \mathrm{C}\right)$ for up to 15 minutes. Similar results were presented by Lopes et al. (2012) with $S$. macranthera seeds submitted to the same temperature for up to 10 minutes. When exposed to water at $90^{\circ} \mathrm{C}$, the results of this study were similar to that of Lopes, noting reduction in GSI values at all time intervals.

Germination started on the third day, ending at the sixth. We observed differences in the germination peaks

Table 3. Germination Speed Index (GSI) of different batches of seeds of S. pendula under different dormancy breaking treatments.

\begin{tabular}{|ccc|}
\hline Treatments & Batch 2011 & Batch 2014 \\
\hline Control & $2.02 \mathrm{~A} \mathrm{a}$ & $2.31 \mathrm{~B} \mathrm{~b}$ \\
\hline Sandpaper $\mathrm{n} .40$ for $0.5^{\prime}$ & $9.90 \mathrm{~A} \mathrm{~d}$ & $24.85 \mathrm{~B} \mathrm{c}$ \\
\hline Water $70{ }^{\circ} \mathrm{C}$ for $5^{\prime}$ & $4.26 \mathrm{~A} \mathrm{~b}$ & $4.89 \mathrm{~B} \mathrm{~d}$ \\
\hline Water $70^{\circ} \mathrm{C}$ for $10^{\prime}$ & $4.57 \mathrm{~A} \mathrm{c}$ & $12.43 \mathrm{~B} \mathrm{e}$ \\
\hline Water $70^{\circ} \mathrm{C}$ for 1' & $4.53 \mathrm{Ac}$ & $15.36 \mathrm{~B} \mathrm{f}$ \\
\hline Water $70^{\circ} \mathrm{C}$ for $20^{\prime}$ & $4.29 \mathrm{~A} \mathrm{~b}$ & $14.2 \mathrm{~B} \mathrm{~g}$ \\
\hline Water $90^{\circ} \mathrm{C}$ for 5' & $2.35 \mathrm{~A}$ & $12.76 \mathrm{~B}$ \\
\hline Water $90^{\circ} \mathrm{C}$ for $10^{\prime}$ & - & $4.75 \mathrm{~d}$ \\
\hline Water $90^{\circ} \mathrm{C}$ for $15^{\prime}$ & - & $0.9 \mathrm{j}$ \\
\hline Water $90^{\circ} \mathrm{C}$ for $20^{\prime}$ & - & $0.86 \mathrm{j}$ \\
\hline $\mathrm{H}_{2} \mathrm{SO}_{4}$ for $5^{\prime}$ & $10.12 \mathrm{~A} \mathrm{~d}$ & $23.7 \mathrm{~B} \mathrm{~h}$ \\
\hline $\mathrm{H}_{2} \mathrm{SO}_{4}$ for $10^{\prime}$ & $9.39 \mathrm{~A} \mathrm{e}$ & $28.15 \mathrm{~B} \mathrm{i}$ \\
\hline $\mathrm{H}_{2} \mathrm{SO}_{4}$ for $15^{\prime}$ & $10.46 \mathrm{~A} \mathrm{f}$ & $28.56 \mathrm{~B} \mathrm{a}$ \\
\hline $\mathrm{H}_{2} \mathrm{SO}_{4}$ for $20^{\prime}$ & $10.96 \mathrm{~A} \mathrm{~g}$ & $28.73 \mathrm{~B} \mathrm{a}$ \\
\hline
\end{tabular}

Means followed by the same capital letter in line and lowercase in the column do not differ ( $5 \%$ Tukey test). ' $=$ Minutes. 


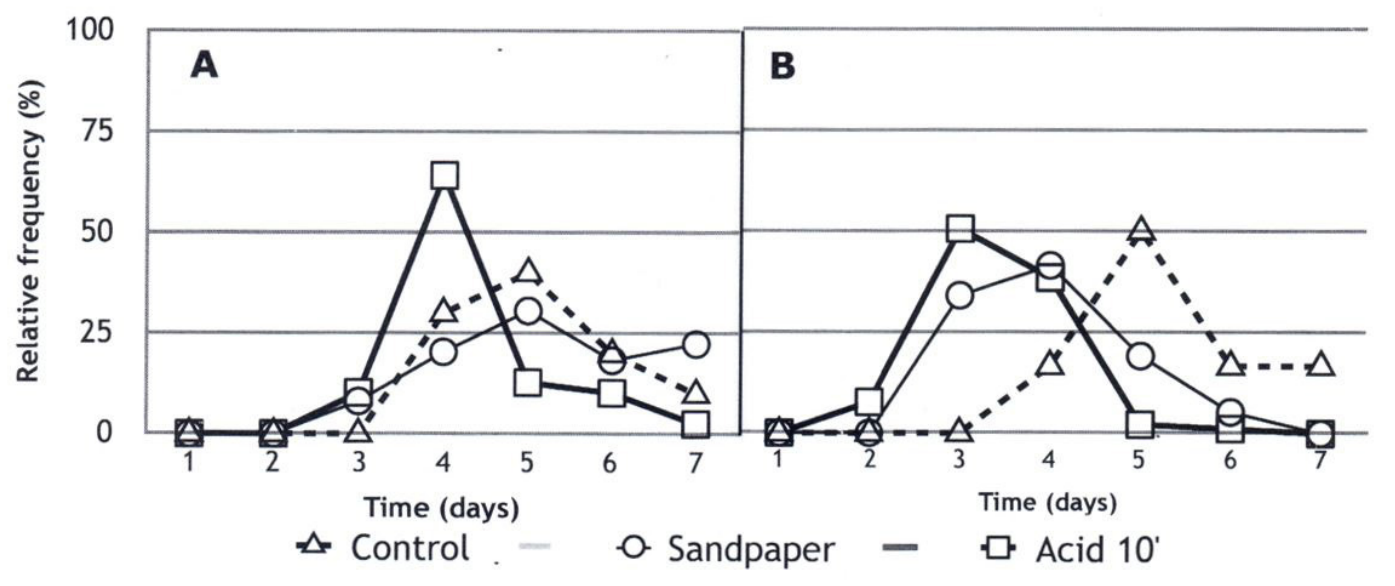

Figure 3. Relative frequency of S. pendula seed germination after a few treatments: (A) Batch 2011; (B) Batch 2014.

in the relative frequencies of the treatments, which had better germination percentage (acid 10' and sandpaper) when compared to control. Thus, the highest number of germinated seeds was observed at the fifth day. In the others treatments this value was verified between the third and fourth days, having reached in the latter about $60 \%$ in the treatment with $\mathrm{H}_{2} \mathrm{SO}_{4}$ for 10 minutes (Figure 3). Both in the treatment with acid as in the mechanical scarification of the seed, the germination was faster and uniform. These results are in agreement with Menezes Silva et al. (2011) who submitted seeds of S. virgata, other species from Fabaceae family, which is pioneer and dormant, to the same chemical and mechanical treatments, and verified similar germination rate, but the chemical scarification has noticed slight non-uniformity after the first germination peak.

The comparison of the two batches showed again a higher speed in the germination of seeds treated with acid and sandpaper. To the 2014 batch it was established a germination peak 1 day prior to the 2011 batch. This can be explained by the higher vigor of the newer batch of seeds, thereby ensuring a faster metabolic reactivation as well as more efficient development of the plants (Oliveira et al., 2015).

In the natural environment, mainly due to dormancy, it is expected a higher heterogeneity of germination with distribution spread over time, presenting an adaptive advantage. However, determining what plant constitutes an ecological advantage is a disadvantage for growers who seek greater uniformity of germination because the logistics of marketing, transportation and planting (Bortolini et al., 2011).
Although the use of acid has been indicated by Alzugaray et al. (2007) and is considered more practical than the sandpaper to large scale (Oliveira et al., 2003), such method can be dangerous and unfeasible financially and ecologically because of its high commercial value and residues effect to the water (Lin, 1999). Thus, the scarification with sandpaper is the safest and most efficient method (environmentally, sustainable and cheap) for breaking dormancy in S. pendula seeds.

\section{CONCLUSIONS}

The S. pendula seeds present a physical barrier that prevents imbibition during its return to growth, so characterized as dormant.

The hot water treatment, both as $70{ }^{\circ} \mathrm{C}$ to $90{ }^{\circ} \mathrm{C}$ was not feasible to overcome the dormancy. Although the treatment with sulfuric acid was an effective and practical way to overcome the dormancy, it can be dangerous and unfeasible financially and ecologically. Therefore, the mechanical scarification for $0.5 \mathrm{~min}$ is the suggested treatment as efficient in terms of cost benefit to overcome dormancy of S. pendula.

\section{ACKNOWLEDGEMENTS}

The authors are grateful to Coordenação de aperfeiçoamento de Pessoal de Nível Superior (CAPES), Universidade Federal do Espírito Santo (UFES), and the editors' reviews. 


\section{SUBMISSION STATUS}

Received: 3 jan., 2017

Accepted: 24 jan., 2018

\section{CORRESPONDENCE TO}

\section{Josinei Rodrigues Filho}

Departamento de Ciências Biológicas, Universidade Federal do Espírito Santo - UFES, Avenida Fernando Ferrari, 514, Goiabeiras, CEP 29075-910, Vitória, ES, Brasil e-mail: josinei.rf@hotmail.com

\section{FINANCIAL SUPPORT}

\section{FAPES}

\section{REFERENCES}

Agra PFM, Guedes RS, Silva MLM, Souza VC, Andrade LA, Alves EU. Métodos para superação da dormência de sementes de Parkinsonia aculeata L. Semina: Ciências Agrárias 2015; 36(3): 1191-1202. http://dx.doi.org/10.5433/16790359.2015v36n3p1191.

Aguiar FFA, Tavares AR, Kanashiro S, Luz PB, Santos NA Jr. Germination of Dalbergia nigra (Vell.)Allemao ex Benth.(Fabaceae-Papilionoideae) during storage. Ciência e Agrotecnologia 2010; 34(spe): 1624-1629. http://dx.doi. org/10.1590/S1413-70542010000700006.

Albuquerque KS, Guimarães RM, Almeida IF, Clemente ADCS. Métodos para a superação da dormência em sementes de sucupira-preta (Bowdichia virgilioides Kunth.). Ciência e Agrotecnologia 2007; 31(6): 1716-1721. http:// dx.doi.org/10.1590/S1413-70542007000600017.

Alves AU, Dornelas CSM, Bruno RDLA, Andrade LAD, Alves EU. Superação da dormência em sementes de Bauhinia divaricata L. Acta Botanica Brasílica 2004; 18(4): 871-879. http://dx.doi.org/10.1590/S0102-33062004000400018.

Alves FM, Sartori ÂLB. Caesalpinioideae (Leguminosae) de um remanescente de Chaco em Porto Murtinho, Mato Grosso do Sul, Brasil. Rodriguésia 2009; 60(3): 531-550. http://dx.doi.org/10.1590/2175-7860200960305.

Alzugaray C, Carnevale NJ, Salinas AR, Moreno L, Boggio JP. Calidad de semillas de árboles y arbustos autóctonos de La Cuña Boscosa Santafesina. Análisis de Semillas 2007; 1(1): 99-104.

Banzatto DA, Kronka SN. Experimentação agrícola. 4. ed. Jaboticabal: Funep; 2006.
Baskin CC, Baskin JM. A classification system for seed dormancy. Seed Science Research 2004; 14(1): 1-16. http:// dx.doi.org/10.1079/SSR2003150.

Bewley DD, Black M. Seeds: physiology of development and germination. New York: Plenum; 1994. http://dx.doi. org/10.1007/978-1-4899-1002-8.

Borges S, Borges EEDL, Correa PC, Brune A. Equilíbrio higroscópico e viabilidade de sementes de angico-vermelho (Anadenanthera peregrina (L.) Speng) em diferentes condições ambientais de armazenamento. Scientia Forestalis 2009; 37(84): 475-481.

Bortolini MF, Koehler HS, Zuffellato-Ribas KC, Malavasi MDM, Fortes AMT. Superação de dormência em sementes de Gleditschia amorphoides Taub. Ciência Rural 2011; 41(5): 823-827. http://dx.doi.org/10.1590/ S0103-84782011000500014.

Brasil. Ministério da Agricultura, Pecuária e Abastecimento - MAPA. Regras para análise de sementes. 1. ed. Brasília: ACS; 2009.

Calil AC, Leonhardt C, De Souza LDS, Da Silva VS. Influência do armazenamento em câmara fria sobre a viabilidade de sementes de Calliandra foliolosa Benth. (Leguminosae-Mimosoideae). Revista Brasileira de Biociências 2008; 5(1): 774-776.

Carvalho LR, Silva EAA, Davide AC. Classificação de sementes florestais quanto ao comportamento no armazenamento. Revista Brasileira de Sementes 2006; 28(2): 15-25. http:// dx.doi.org/10.1590/S0101-31222006000200003.

Dutra TR, Massad MD, Sarmento MFQ, Oliveira JC. Substratos alternativos e métodos de quebra de dormência para produção de mudas de canafístula. Ceres 2015; 60(1): 72-78. http://dx.doi.org/10.1590/S0034-737X2013000100011.

Ferreira AG, Borghetti F. Germinação: do básico ao aplicado. Porto Alegre: Artmed; 2004.

Ferreira RA, Davide AC, Motta MS. Vigor e viabilidade de sementes de Senna multijuga (Rich.) Irwin et Barn. e Senna macranthera (Collad.) Irwin et Barn., num banco de sementes em solo de viveiro. Revista Brasileira de Sementes 2004; 26(1): 24-31. http://dx.doi.org/10.1590/ S0101-31222004000100004.

Flávio JJP. Qualidade fisiológica de sementes de Senna multijuga de diferentes procedências do Estado de São Paulo [tese]. São Paulo: Faculdade de Ciências Agrárias e Veterinárias de Jaboticabal, Universidade Estadual Paulista "Júlio de Mesquita Filho"; 2014.

Floriano EP. Germinação e dormência de sementes florestais. 2. ed. Santa Rosa: Anorgs; 2004.

Fowler JAP, Bianchetti A. Dormência em sementes florestais. Colombo: Embrapa Florestas; 2000.

Garcia C, Coelho CMM, Maraschin M, Oliveira LM. Conservação da viabilidade e vigor de sementes de Araucaria angustifolia (Bert.) O. Kuntze durante o 
armazenamento. Ciência Florestal 2014; 24(4): 857-867. http://dx.doi.org/10.5902/1980509816586.

Garcia JP. Avaliação da qualidade fisiológica e caracterização morfológica das sementes de duas espécies nativas do Cerrado [monografia]. Brasília: Departamento de Engenharia Florestal, Universidade de Brasília; 2013.

Goudel F, Shibata M, Coelho CMM, Miller PRM. Fruit biometry and seed germination of Syagrus romanzoffiana (Cham.) Glassm. Acta Botanica Brasílica 2013; 27(1): 147154. http://dx.doi.org/10.1590/S0102-33062013000100015.

Guedes RS, Alves EU, Santos-Moura SDS, Costa EG, Melo PAFR. Tratamentos para superar dormência de sementes de Cassia fistula L. Biotemas 2013; 26(4): 11-22. http:// dx.doi.org/10.5007/2175-7925.2013v26n4p11.

Hilhorst HW. Definitions and hypotheses of seed dormancy. In: Bradford KJ, Nonogaki H, editors. Seed development, dormancy and germination. Oxford: Blackwell Publishing; 2007. http://dx.doi.org/10.1002/9780470988848.ch3.

Johansen DA. Plant microtechique. New York: McGrawHill Book; 1940.

Labouriau LG, Valadares MEB. On the germination of seeds Calotropisprocera (Ait.) Ait.f. Anais da Academia Brasileira de Ciências 1976; 48(2): 263-284.

Lin SS. Quebra de dormência de sementes do Feijão-Mungo. Pesquisa Agropecuária Brasileira 1999; 34(6): 1081-1086. http://dx.doi.org/10.1590/S0100-204X1999000600021.

Lopes JC, Barbosa LG, Capucho MT. Biometria, dormência e viabilidade de sementes de Senna macranthera. Nucleus 2012; 9(2): 247-256. http://dx.doi.org/10.3738/1982.2278.795.

Maeda JA, Ungaro MRG, Lago AA, Razera LF. Estádio de maturação e qualidade de sementes de girassol. Bragantia 1987; 46(1): 35-44. http://dx.doi.org/10.1590/ S0006-87051987000100005.

Maguire JD. Speeds of germination-aid selection and evaluation for seedling emergence and vigor. Crop Science 1962; 2(1): 176-177. http://dx.doi.org/10.2135/cropsci19 62.0011183X000200020033x.

Marcos J Fo. Deterioração de sementes. In: Marcos J Fo, editor. Fisiologia de sementes de plantas cultivadas. Piracicaba: FEALQ; 2005.

Menezes Silva PE, Santiago EF, Daloso DM, Silva EM, Oliveira Silva J. Quebra de dormência em sementes de Sesbania virgata (Cav.) Pers. Idesia 2011; 29(2): 39-45. http://dx.doi.org/10.4067/S0718-34292011000200005.

Oliveira ACS, Martins GN, Silva RF, Vieira HD. Testes de vigor em sementes baseados no desempenho de plântulas. InterSciencePlace 2015; 1(4): 1-21.

Oliveira LM, Davide AC, Carvalho MLM. Avaliação de métodos para quebra da dormência e para a desinfestação de sementes de Canafístula (Peltophorum dubium (Sprengel) Taubert). Revista Árvore 2003; 27(5): 597-603. http:// dx.doi.org/10.1590/S0100-67622003000500001.
Pereira PEE, Jacobi US. Avaliação da maturidade, superação da dormência de sementes e crescimento inicial da raiz de Myrsine parvifolia A. DC.(Primulaceae). Iheringia. Série Botânica 2014; 69(2): 293-301.

Pereira VJ, Santana DG, Lobo GA, Brandão NAL, Soares DC. Eficiência dos tratamentos para a superação ou quebra de dormência de sementes de Fabaceae. Revista de Ciências Agrárias 2014; 37(2): 187-197.

Perez SCJGA. Envoltórios. In: Ferreira AG, Borguetti F, editors. Germinação do básico ao aplicado. Porto Alegre: Artmed; 2004.

Pinho DS, Borges EEL, Corte VB, Nasser LCB. Avaliação da qualidade fisiológica de sementes de Anadenanthera peregrina (L.) Speg. durante o armazenamento. Revista Árvore 2009; 33(1): 27-33. http://dx.doi.org/10.1590/ S0100-67622009000100004.

Pozitano M. Conservação da viabilidade de sementes de Senna macranthera por meio de recobrimento [tese]. São Paulo: Faculdade de Engenharia Química, Universidade Estadual de Campinas; 2011.

Ribeiro JI Jr. Métodos estatísticos aplicados à melhoria da qualidade. 1. ed. Viçosa: Editora UFV; 2012.

Rodrigues AG Jr. Aspectos morfológicos da dormência física, tolerância à dessecação e armazenamento de sementes de Senna multijuga (Rich.) Irwin et Barn.(Fabaceae) durante a germinação [dissertação]. Lavras: Programa de Pós graduação em Engenharia Florestal, Universidade Federal de Lavras; 2013.

Rodrigues RS, Flores AS, Miotto STS, Baptista LRDM. The genus Senna (Leguminosae, Caesalpinioideae) in Rio Grande do Sul State, Brazil. Acta Botanica Brasílica 2005; 19(1): 1-16. http://dx.doi.org/10.1590/S010233062005000100002 .

Santarém ER, Aquila MEA. Influência de métodos de superação de dormência e do armazenamento na germinação de sementes de Senna macranthera (Colladon) Irwin \& Barneby (Leguminosae). Revista Brasileira de Sementes 1995; 17(2): 205-209. http://dx.doi.org/10.17801/01013122/rbs.v17n2p205-209.

Santos CMR, Menezes ND, Villela FA. Alterações fisiológicas e bioquímicas em sementes de feijão envelhecidas artificialmente. Revista Brasileira de Sementes 2004; 26(1): 110-119. http://dx.doi.org/10.1590/S010131222004000100017

Silva FD, Porto AG, Pascuali LC, Silva FD. Viabilidade do armazenamento de sementes em diferentes embalagens para pequenas propriedades rurais. Revista de Ciências Agro-ambientais 2010; 8(1): 45-56.

Smaniotto TDS, Resende O, Marçal KA, Oliveira DEC, Simon GA. Qualidade fisiológica das sementes de soja armazenadas em diferentes condições. Revista Brasileira de Engenharia Agrícola e Ambiental 2014; 18(4): 446-453. http://dx.doi.org/10.1590/S1415-43662014000400013. 
Souza VC, Bortoluzzi RLC. Senna. In: Jardim Botânico do Rio de Janeiro - JBRJ. Lista de Espécies da Flora do Brasil [online]. Rio de Janeiro: JBRJ; 2016 [cited 2016 July 14]. Available from: http://floradobrasil.jbrj.gov.br/jabot/ FichaPublicaTaxonUC/FichaPublicaTaxonUC.do?id=FB23

Souza VC, Bruno RLA, Andrade LA. Vigor de sementes armazenadas de ipê-amarelo Tabebuia serratifolia (Vahl.)
Nich. Revista Árvore 2005; 29(6): 833-841. http://dx.doi. org/10.1590/S0100-67622005000600001.

Topanotti LR, Pereira PH, Bechara FC. Germinação de sementes de Senna obtusifolia (L.) Hs irwin \& barneby (Fabaceae) visando a restauração de áreas degradadas. Ciências Biológicas e da Saúde 2014; 20(2): 125-129. http://dx.doi.org/10.5212/Publ.Biologicas.v.20i2.0004. 